\title{
Synthesis of new biphenyl-substituted quinoline derivatives, preliminary screening and docking studies
}

\author{
NELLISARA D SHASHIKUMAR ${ }^{1, *}$, GANGANAIKA KRISHNAMURTHY ${ }^{1}$, \\ HALEHATTI S BHOJYANAIK ${ }^{2}$, MAYASANDRA R LOKESH ${ }^{1}$ and \\ KAGINALLI S JITHENDRAKUMARA ${ }^{1}$ \\ ${ }^{1}$ Department of Chemistry, Sahyadri Science College, Shimoga 577 451, India \\ ${ }^{2}$ Department of PG Studies and Research in Industrial Chemistry, School of Chemical Sciences, \\ Kuvempu University, Shankaraghatta 577 451, Shimoga, India \\ e-mail: shashikumarnd@gmail.com
}

MS received 6 April 2013; revised 10 September 2013; accepted 18 September 2013

\begin{abstract}
New quinoline derivatives containing biphenyl ring were synthesized and characterized by IR, $1 \mathrm{H}$ NMR and mass spectral studies. The synthesized compounds were screened for antimicrobial, anthelmintic activities as well as free radical scavenging property against the DPPH radical. The minimum inhibition concentration values showed promising inhibiting activity and are potent biological agents. The compounds showed minimum binding energy towards $\beta$-tubulin. The compounds $11 a, 11 \mathbf{c}, 13 \mathbf{c}$ and $13 \mathbf{d}$ have good affinity towards the active pocket and may be considered as a good inhibitor of $\beta$-tubulin.
\end{abstract}

Keywords. Quinoline biphenyl; antioxidant; anthelmintic; docking; $\beta$-tubulin.

\section{Introduction}

Quinoline is a heterocyclic scaffold of paramount importance to living beings. Several quinoline derivatives isolated from natural resources or prepared synthetically are significant with respect to medicinal chemistry and biomedical use. The bark of Cinchona plant (also known as Jesuit's or Cardinal's bark) containing quinine was utilized to treat palpitations, ${ }^{1,2}$ fevers and tertians, since more than 200 years. The compounds containing the quinoline motif are most widely used as antimalarials, ${ }^{3}$ antibacterials, ${ }^{4}$ antifungals, ${ }^{5}$ and anticancer agents. ${ }^{6}$ Additionally, quinoline derivatives find use in the synthesis of fungicides, virucides, biocides, alkaloids, rubber chemicals and flavouring agents. ${ }^{7}$ They are also used as polymers, catalysts, corrosion inhibitors, preservatives and as solvents for resins and terpenes. Furthermore, these compounds find applications in transition metal catalysis for uniform polymerization and luminescence chemistry. ${ }^{8,9}$ Owing to this, the synthesis of substituted quinolines has been a subject of great focus in organic chemistry.

\section{Experimental}

All the reagents and solvents were used as received from commercial suppliers, unless otherwise stated. All chemicals used for the synthesis were of analytical grade or laboratory grade and purchased from HiMedia Laboratories Pvt. Ltd., Sigma Chemical Co., USA, E Merck, Germany, Sarabhai Merck Company, India, and specialty chemicals were procured as samples from commercial suppliers in India. All equipments were inspected visually for cleanliness and integrity before use. Mass spectra of the synthesized compounds were recorded on Agilent 6320 Ion Trap mass spectrometer. IR spectra were recorded on a Shimadzu IR470 spectrometer. ${ }^{1} \mathrm{H}$ NMR spectra were recorded on a Bruker DRX-300 Avance spectrometer (300 MHz). Melting point was determined using a Buchi melting point B-540 model and are uncorrected.

\subsection{Synthesis of biphenyl derivatives $\mathbf{4 a}-\boldsymbol{b}$}

The compounds $\mathbf{4 a}$ and $\mathbf{4 b}$ were synthesized by the literature methods. ${ }^{10-14}$

\subsection{Synthesis of quinoline derivatives $6,7 \boldsymbol{a}, 7 \boldsymbol{b}$}

The product 2-chloro-3-formylquinoline $\mathbf{6}$ synthesized by the reported methods and the compound $\mathbf{6}$ was

*For correspondence 
converted to $7 \mathbf{a}$ by hydrolysing the $-\mathrm{Cl}$ group by refluxing with aqueous acetic acid. The compound 7b was obtained by treating the compound $\mathbf{6}$ with $\mathrm{Na}_{2} \mathrm{~S} /$ DMF. ${ }^{15,16}$

\subsection{General procedure for the synthesis of $11 a, 11 c$,} $13 a$ and $13 c$

The compounds $\mathbf{7 a} / \mathbf{7 b}(20 \mathrm{mmol})$, were mixed with $20 \mathrm{mmol}$ of bromomethylbiphenyl-2'-carboxylic acid methyl ester $4 \mathbf{a}$ and $20 \mathrm{mmol}$ of $\mathrm{K}_{2} \mathrm{CO}_{3}$ in $20 \mathrm{~mL}$ DMF was stirred for $2-3 \mathrm{~h}$ at room temperature. After the reaction, it was poured into crushed ice. The separated solid was filtered and washed with $100 \mathrm{~mL}$ water. The obtained precipitate $(10 \mathrm{mmol})$ and $10 \mathrm{mmol}$ of corresponding amines were dissolved in $20 \mathrm{~mL}$ of methanol and refluxed for $4-5 \mathrm{~h}$. Progress of the reaction was monitored by TLC (methanol : MDC in $2: 8$ ratio). After completion of the reaction, it was poured into ice-cold water $(50 \mathrm{~mL})$ and the solid separated was filtered and used without purification for the next step. The obtained solid was dissolved in methanol $(25 \mathrm{~mL})$ and mixed with a solution of $25 \mathrm{mmol} \mathrm{KOH}$ in $20 \mathrm{~mL}$ of water. The reaction mixture was refluxed for $2 \mathrm{~h}$. Then, the methanol was distilled off. To the reaction mixture, $30 \mathrm{~mL}$ of distilled water was added and acidified to $\mathrm{pH}$ 3-4 using $0.1 \mathrm{~N} \mathrm{HCl}$ solution. Filtered the solid, washed with $10 \mathrm{~mL}$ of water and dried in an oven under reduced pressure for $5 \mathrm{~h}$ at $50^{\circ} \mathrm{C}$.

\subsection{General procedure for synthesis of $11 b, 11 d, 13 b$ and 13d}

A solution of the compound $7 \mathbf{a} / \mathbf{7 b} \quad(20 \mathrm{mmol})$ is stirred with bromomethylbiphenyl-2'-(N-triphenylmethyl)tetrazole $4 \mathrm{~b}(20 \mathrm{mmol})$ and $\mathrm{K}_{2} \mathrm{CO}_{3}(20 \mathrm{mmol})$ in $20 \mathrm{~mL}$ of DMF at room temperature for $2-3 \mathrm{~h}$. The reaction mixture was poured into crushed ice, filtered and washed to get intermediate. The obtained precipitate $(10 \mathrm{mmol})$ was dissolved in $20 \mathrm{~mL}$ of methanol and $10 \mathrm{mmol}$ of corresponding amines was added. The resulting mixture was refluxed for $4-5 \mathrm{~h}$. The reaction was monitored by TLC (methanol : MDC in $2: 8$ ratio). After completion of the reaction, it was poured into ice-cold water $(50 \mathrm{~mL})$ and filtered. The product was used without purification for the next step. The obtained product was dissolved in $20 \mathrm{~mL}$ of methanol and refluxed with $25 \mathrm{mmol}$ of aqueous $\mathrm{KOH}$, the completion of reaction checked by TLC (methanol : MDC in 1 : 10 ratio). After completion of the reaction, $1 \mathrm{~N} \mathrm{HCl}(5 \mathrm{~mL})$ was added and refluxed for $2 \mathrm{~h}$. The solid obtained after the complete removal of solvent by distillation was stirred with $10 \mathrm{~mL}$ of distilled water for $30 \mathrm{~min}$. The solid so obtained was filtered and separated, washed with $10 \mathrm{~mL}$ of distilled water and dried in an oven under reduced pressure for $5 \mathrm{~h}$ at $50^{\circ} \mathrm{C}$.

2.4a 4'-[2-Oxo-3-([1,2,4]triazol-4-yliminomethyl)2H-quinolin-1-ylmethyl]-biphenyl-2-carboxylic acid: IR: $3413,1763,1701$ and $1616 \mathrm{~cm}^{-1}$ for $-\mathrm{OH}, \mathrm{C}=\mathrm{O}$ and $\mathrm{C}=\mathrm{N}$, respectively. ${ }^{1} \mathrm{H}-\mathrm{NMR}(300 \mathrm{MHz}$, DMSO$\left.d_{6}\right): \delta 7.3-8.7(\mathrm{~m}, 16 \mathrm{H}, \mathrm{Ar}-\mathrm{H}$ and $-\mathrm{HC}=\mathrm{N}-), 4.25$ (s, 2H, -CH2-Ar), 11.8 (s, 1H, - $\mathrm{COOH}),{ }^{13} \mathrm{C} \mathrm{NMR}$ $400 \mathrm{MHz}, \mathrm{DMSO}-d_{6}: \delta 169.4(-\mathrm{COOH}), 164.5(\mathrm{C}=\mathrm{O})$, $163.7(\mathrm{C}=\mathrm{N}), 148.0$ (triazole $\mathrm{C}=\mathrm{N}), 120-140(\mathrm{Ar})$, $47.7\left(-\mathrm{CH}_{2}-\mathrm{N}\right)$.

$2.4 \mathrm{~b} \quad 4$ - $\{2-O x o-3-[(4-[1,2,4]$ triazol-1-ylmethyl-phenylimino)-methyl]-2H-quinolin-1-ylmethyl\}-biphenyl-2carboxylic acid: IR: 3403, 1758.3, 1698 and $1618 \mathrm{~cm}^{-1}$ for $-\mathrm{OH}, \mathrm{C}=\mathrm{O}$ and $\mathrm{C}=\mathrm{N}$, respectively. ${ }^{1} \mathrm{H}-\mathrm{NMR}\left(300 \mathrm{MHz}, \mathrm{DMSO}-d_{6}\right): \delta 7.3-8.7(\mathrm{~m}, 20 \mathrm{H}$, Ar-H and $-\mathrm{HC}=\mathrm{N}-), 4.25\left(\mathrm{~s}, 2 \mathrm{H},-\mathrm{CH}_{2}-\mathrm{Ar}\right), 4.9(\mathrm{~s}$, $2 \mathrm{H},-\mathrm{CH}_{2}$-triazole), $11.9(\mathrm{~s}, 1 \mathrm{H},-\mathrm{COOH}) .{ }^{13} \mathrm{C} \mathrm{NMR}$ $400 \mathrm{MHz}, \mathrm{DMSO}-d_{6}: \delta 164.1(\mathrm{C}=\mathrm{O}), 163.5$ (tetrazole C), $163.7(\mathrm{C}=\mathrm{N}), 148.0($ triazole $\mathrm{C}=\mathrm{N}), 120-140(\mathrm{Ar})$, $47.7\left(-\mathrm{CH}_{2}-\mathrm{N}\right)$.

2.4c 1-[2'-(1H-tetrazol-5-yl)-biphenyl-4-ylmethyl]3-([1,2,4]triazol-4-yliminomethyl-1H-quinolin-2-one: IR: $3465,1710,1698$ and $1618 \mathrm{~cm}^{-1}$ for $\mathrm{NH}$ and $\mathrm{C}=\mathrm{N}$, respectively. ${ }^{1} \mathrm{H}-\mathrm{NMR}\left(300 \mathrm{MHz}, \mathrm{DMSO}-d_{6}\right)$ : $\delta$ 6.9-8.5 (m, 16H, Ar-H and $-\mathrm{HC}=\mathrm{N}-), 4.22(\mathrm{~s}, 2 \mathrm{H}$, $\left.-\mathrm{CH}_{2}-\mathrm{Ar}\right), 5.6(\mathrm{~b}, 1 \mathrm{H},-\mathrm{NH}) .{ }^{13} \mathrm{C} \mathrm{NMR} 400 \mathrm{MHz}$, DMSO- $d_{6}: \delta 169.4(-\mathrm{COOH}), 164.1(\mathrm{C}=\mathrm{O}), 153.5$ $(\mathrm{C}=\mathrm{N}), 143.6 \& 151.3($ triazole $\mathrm{C}=\mathrm{N}), 120-146(\mathrm{Ar})$, $55.7 \& 47.7\left(-\mathrm{CH}_{2}-\right)$.

2.4d 1-[2'-(1H-tetrazol-5-yl)-biphenyl-4-ylmethyl]3-[(4-[1,2,4]triazol-1-ylmethyl-phenylimino)-methyl]1H-quinolin-2-one: IR: 3445, 1710, 1698 and $1618 \mathrm{~cm}^{-1}$ for $\mathrm{NH}$ and $\mathrm{C}=\mathrm{N}$, respectively. ${ }^{1} \mathrm{H}-\mathrm{NMR}$ $\left(300 \mathrm{MHz}, \mathrm{DMSO}-d_{6}\right): \delta 7.2-8.6(\mathrm{~m}, 20 \mathrm{H}, \mathrm{Ar}-\mathrm{H}$ and $-\mathrm{HC}=\mathrm{N}-), 4.18\left(\mathrm{~s}, 2 \mathrm{H},-\mathrm{CH}_{2}-\mathrm{Ar}\right), 4.82\left(\mathrm{~s}, 2 \mathrm{H},-\mathrm{CH}_{2}-\right.$ triazole), $5.75(\mathrm{~b}, 1 \mathrm{H},-\mathrm{NH}) .{ }^{13} \mathrm{C} \mathrm{NMR} 400 \mathrm{MHz}$, DMSO- $d_{6}: \delta 164.1(\mathrm{C}=\mathrm{O}), 163.5$ (tetrazole $\left.\mathrm{C}\right), 153.5$ $(\mathrm{C}=\mathrm{N}), 143.6 \& 151.3($ triazole $\mathrm{C}=\mathrm{N}), 120-140(\mathrm{Ar})$, $47.7\left(-\mathrm{CH}_{2}-\mathrm{N}\right)$.

$2.4 \mathrm{e} \quad 4$ '-[3-([1,2,4]Triazol-4-yliminomethyl)-quinolin2-ylsulphanylmethyl]-biphenyl-2-carboxylic acid: IR: $3415,1770,1705$ and $1612 \mathrm{~cm}^{-1}$ for $-\mathrm{OH}, \mathrm{C}=\mathrm{O}$ and 
$\mathrm{C}=\mathrm{N}$, respectively. ${ }^{1} \mathrm{H}-\mathrm{NMR}\left(300 \mathrm{MHz}, \mathrm{DMSO}-d_{6}\right)$ : $\delta$ 6.9-8.4 (m, 16H, Ar-H and $-\mathrm{HC}=\mathrm{N}-), 4.32(\mathrm{~s}, 2 \mathrm{H}$, $-\mathrm{CH}_{2}-\mathrm{Ar}$ ), 11.2 (s, $\left.1 \mathrm{H},-\mathrm{COOH}\right) .{ }^{13} \mathrm{C} \mathrm{NMR} 400 \mathrm{MHz}$, DMSO- $d_{6}: \delta 169.4(-\mathrm{COOH}), 160.8(\mathrm{~S}-\mathrm{C}=\mathrm{N}$ ring), $157.0(\mathrm{C}=\mathrm{N}), 148.2($ triazole $\mathrm{C}=\mathrm{N}), 121.3-148.7(\mathrm{Ar})$, $38.5\left(-\mathrm{CH}_{2}-\mathrm{S}\right)$.

$2.4 \mathrm{f} \quad 4$-\{3-[(4-[1,2,4]triazol-1-ylmethyl-phenylimino $)-$ methyl]-quinolin-2-ylsulphanylmethyl\}-biphenyl-2carboxylic acid: IR: 3403, 1758, 1698 and $1618 \mathrm{~cm}^{-1}$ for $-\mathrm{OH}, \mathrm{C}=\mathrm{O}$ and $\mathrm{C}=\mathrm{N}$, respectively. ${ }^{1} \mathrm{H}-\mathrm{NMR}$ $\left(300 \mathrm{MHz}, \mathrm{DMSO}-d_{6}\right): \delta 7.2-8.6(\mathrm{~m}, 20 \mathrm{H}, \mathrm{Ar}-\mathrm{H}$ and $-\mathrm{HC}=\mathrm{N}-), 4.42\left(\mathrm{~s}, 2 \mathrm{H},-\mathrm{CH}_{2}-\mathrm{Ar}\right), 4.85\left(\mathrm{~s}, 2 \mathrm{H},-\mathrm{CH}_{2}-\right.$ triazole), $11.74(\mathrm{~s}, 1 \mathrm{H},-\mathrm{COOH}),{ }^{13} \mathrm{C}$ NMR $400 \mathrm{MHz}$, DMSO- $d_{6}: \delta 163.5$ (tetrazole $\mathrm{C}$ ), $160.6(\mathrm{~S}-\mathrm{C}=\mathrm{N}$ ring), $157.2(\mathrm{C}=\mathrm{N}), 148.6 \& 151.3($ triazole $\mathrm{C}=\mathrm{N}), 120-148$ (Ar), $38.5\left(-\mathrm{CH}_{2}-\mathrm{S}\right)$.

$2.4 \mathrm{~g}\left\{2-\left[2^{\prime}-(1 \mathrm{H}\right.\right.$-tetrazol-5-yl)-biphenyl-4-ylmethylsulphanyl]-quinolin-3-ylmethylene $]$-[1,2,4]triazol-4-ylamine: IR: 3340, 1703 and $1611 \mathrm{~cm}^{-1}$ for $\mathrm{NH}$ and $\mathrm{C}=\mathrm{N}$, respectively. ${ }^{1} \mathrm{H}-\mathrm{NMR}\left(300 \mathrm{MHz}, \mathrm{DMSO}-d_{6}\right)$ : $\delta 7.0-8.5(\mathrm{~m}, 16 \mathrm{H}, \mathrm{Ar}-\mathrm{H}$ and $-\mathrm{HC}=\mathrm{N}-), 4.34(\mathrm{~s}, 2 \mathrm{H}$, $-\mathrm{CH}_{2}-\mathrm{Ar}$ ), 5.3 (b, $\left.1 \mathrm{H},-\mathrm{NH}\right) .{ }^{13} \mathrm{C} \mathrm{NMR} 400 \mathrm{MHz}$, DMSO- $d_{6}: \delta 169.1(-\mathrm{COOH}), 160.6(\mathrm{~S}-\mathrm{C}=\mathrm{N}$ ring $)$, $160.1(\mathrm{C}=\mathrm{N}), 143.6($ triazole $\mathrm{C}=\mathrm{N}), 121.3-148.7(\mathrm{Ar})$, 55.7 (- $\mathrm{CH}_{2}$-triazole), $38.5\left(-\mathrm{CH}_{2}-\mathrm{S}\right)$.

$2.4 \mathrm{~h} \quad\left\{2-\left[2^{\prime}-(1 \mathrm{H}\right.\right.$-tetrazol-5-yl)-biphenyl-4-ylmethylsulphanyl]-quinolin-3-ylmethylene $\}-(4-[1,2,4]$ triazol-1ylmethyl-phenyl)-amine: IR: 1655, 1709 and $3410 \mathrm{~cm}^{-1}$ for $\mathrm{C}=\mathrm{N}$ and $\mathrm{NH}$, respectively. ${ }^{1} \mathrm{H}-\mathrm{NMR}$ $\left(300 \mathrm{MHz}, \mathrm{DMSO}-d_{6}\right): \delta 7.3-8.5(\mathrm{~m}, 20 \mathrm{H}, \mathrm{Ar}-\mathrm{H}$ and $-\mathrm{HC}=\mathrm{N}-), 4.48\left(\mathrm{~s}, 2 \mathrm{H},-\mathrm{CH}_{2}-\mathrm{Ar}\right), 4.78\left(\mathrm{~s}, 2 \mathrm{H},-\mathrm{CH}_{2}-\right.$ triazole), 5.67 (b, $1 \mathrm{H},-\mathrm{NH}) .{ }^{13} \mathrm{C} \mathrm{NMR} 400 \mathrm{MHz}$, DMSO- $d_{6}: \delta 163.5 \quad$ (tetrazole $\left.\quad \mathrm{C}\right), 160.6 \quad(\mathrm{~S}-\mathrm{C}=\mathrm{N}$ ring), $160.1(\mathrm{C}=\mathrm{N}), 143.6 \& 151.3($ triazole $\mathrm{C}=\mathrm{N})$, 122-148.7 (Ar), 55.7 (- $\mathrm{CH}_{2}$-triazole), $38.5\left(-\mathrm{CH}_{2}-\mathrm{S}\right)$.

\section{Results and discussion}

Biphenyl derivatives (4a, b) were synthesized by Suzuki coupling reaction ${ }^{10-13}$ of 2-cyano-1bromobenzene (1) with 4-methylphenyl boronic acid (2) in presence of palladium acetatetriphenylphosphine, in basic condition (TEA) and acetonitrile as solvent to give product 3 (scheme 1). The product 4'-methylbiphenyl-2-carbonitrile 3, was hydrolysed in acidic condition to produce the 4'methylbiphenyl-2-carboxylic acid, followed by bromination gives the product $\mathbf{4 a}$. Also, the product $\mathbf{3}$ was

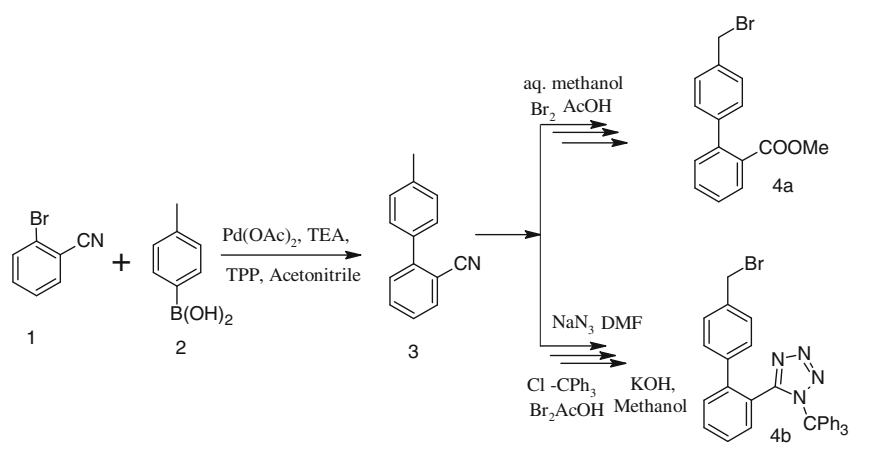

Scheme 1. Synthetic scheme of biphenyl derivatives.

reacted with sodium azide in DMF to give the tetrazole derivative, which on protecting the tetrazole $-\mathrm{NH}$ with triphenylmethyl chloride and followed by bromination yields the product $\mathbf{4 b}$.

2-Chloro-3-formylquinoline (6) has been synthesized by Vilsmeier-Haack reaction using acetanilide, POCl3/DMF (scheme 2). ${ }^{14-16}$ Functional group transformation of formyl group can be used to get new derivatives. The product $\mathbf{6}$ was converted to $7 \mathbf{a}$ by acid hydrolysis of the $-\mathrm{Cl}$ group. On treating $\mathbf{6}$ with $\mathrm{Na}_{2} \mathrm{~S} / \mathrm{DMF}$, substitutes the $-\mathrm{Cl}$ group with $-\mathrm{SH}$ group giving the product $\mathbf{7 b}$ (scheme 2).

The product 7a was converted into new Schiff base derivatives $(\mathbf{1 1 a}-\mathbf{d})$ by condensation with biphenyl derivatives $(\mathbf{4} \mathbf{a}, \mathbf{b})$ in $\mathrm{K}_{2} \mathrm{CO}_{3} / \mathrm{DMF}$, followed by different amines in ethanol and then deprotection of carboxylic acid by base-catalysed hydrolysis in aqueous alcohol (scheme 3). Similarly, the product $\mathbf{7 b}$ was converted to products 13a-d, except the deprotection of tetrazole is done by acid-catalysed hydrolysis (scheme 4).

Structures of the obtained products were confirmed by elemental analysis, IR, ${ }^{1} \mathrm{H}$ NMR and mass spectral data. The IR spectrum of the compounds 11ad recorded as $\mathrm{KBr}$ pellet, showed two peaks between 1700 and $1640 \mathrm{~cm}^{-1}$ for $-\mathrm{C}=\mathrm{N}$ - (outside the ring) and the absence of ring $-\mathrm{C}=\mathrm{N}-$ stretching frequency conforms $\mathrm{N}$-alkylation. Compounds 13a-d showed two peaks between 1700 and $1600 \mathrm{~cm}^{-1}$ for $-\mathrm{C}=\mathrm{N}-$ of inside ring and outside the ring. Also, the absence of aldehyde group frequency in the range of $1700 \mathrm{~cm}^{-1}$ gave an account of the formation of Schiff base.

The proton NMR spectra of the compounds recorded in $\mathrm{CDCl}_{3} / \mathrm{DMSO}-d_{6}$ showed a singlet peak at 12 $10 \mathrm{ppm}$ due to the carboxylic acid proton, a broad peak between 4 and $6 \mathrm{ppm}$ confirms the presence of tetrazole -NH. The biphenyl-substituted two methylic protons appear in the range of 3-4 ppm as a singlet. The mass spectra of the compounds showed molecular ion peak $\mathrm{M}^{+}$at $[\mathrm{M}+1] \mathrm{m} / \mathrm{z}$ values corresponding to the 


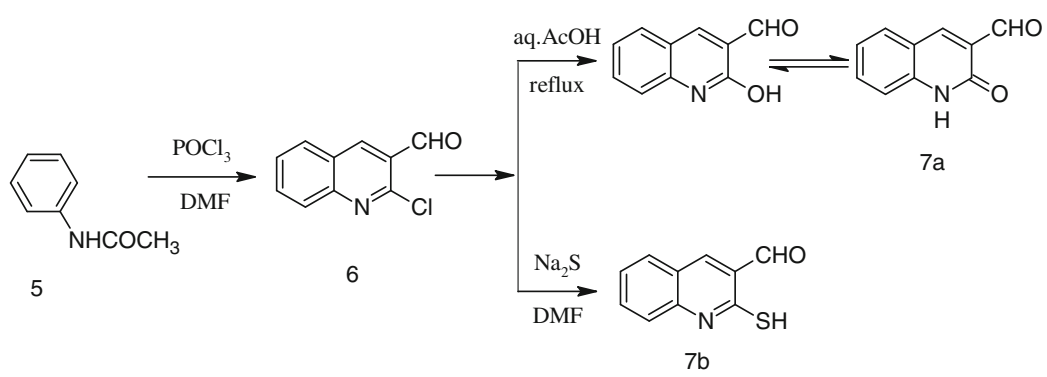

Scheme 2. Synthesis of quinoline derivatives.

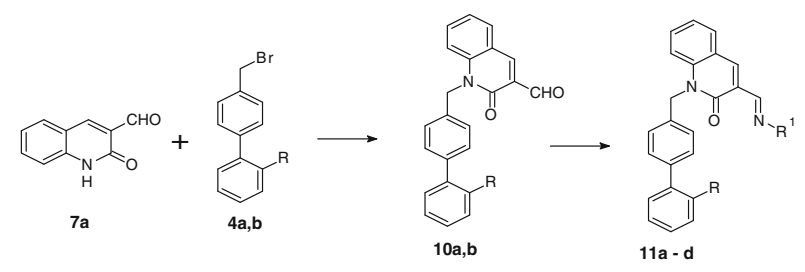

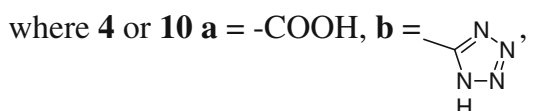

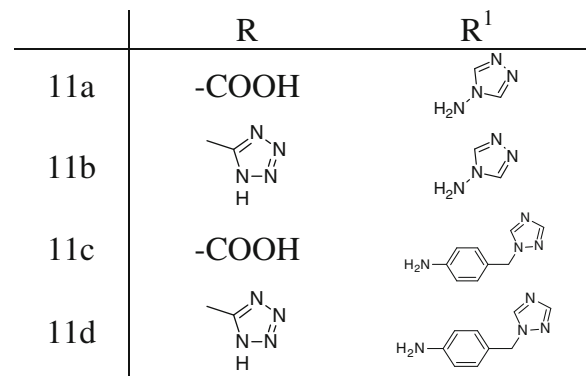

Scheme 3. Synthesis of N-biphenyl quinoline derivatives.

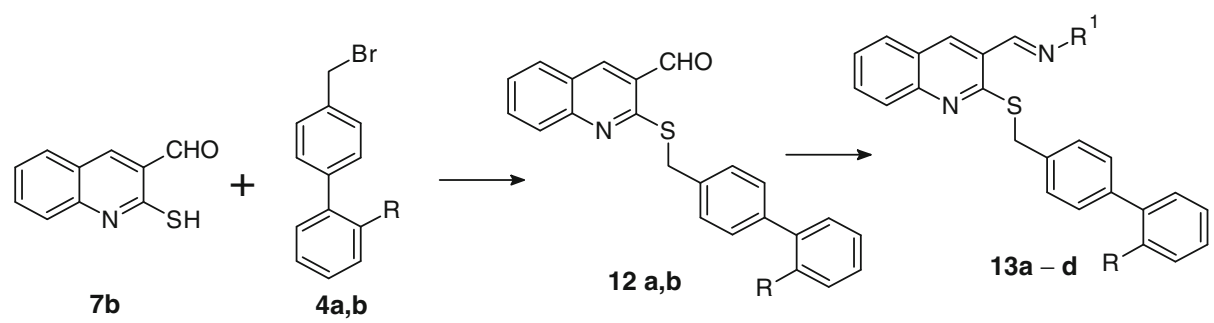

where $\mathbf{4}$ or $\mathbf{1 0} \mathbf{a}=-\mathrm{COOH}, \mathbf{b}=\underset{\substack{N \\ H}}{\mathrm{~N}^{N}-N^{N}}$,

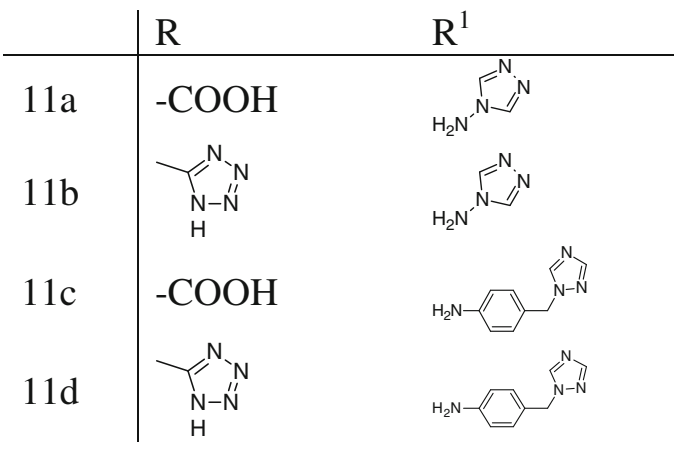

Scheme 4. Synthesis of S-biphenyl quinoline derivatives. 
Table 1. Physical properties, analytical data and mass spectral data of compounds 11a-d and 13a-d.

\begin{tabular}{|c|c|c|c|c|c|c|c|}
\hline \multirow{2}{*}{$\begin{array}{l}\text { Sl. } \\
\text { No. }\end{array}$} & \multirow[b]{2}{*}{ Compound } & \multirow{2}{*}{$\begin{array}{c}\% \\
\text { yield* }\end{array}$} & \multirow{2}{*}{$\begin{array}{l}\text { M.P. } \\
\left(\text { in }{ }^{\circ} \mathrm{C}\right)\end{array}$} & \multicolumn{3}{|c|}{ Elemental analysis } & \multirow{2}{*}{$\begin{array}{c}M / z \\
\text { value }\end{array}$} \\
\hline & & & & $\mathrm{C}$ & $\mathrm{H}$ & $\mathrm{N}$ & \\
\hline 1 & 11a & 67.8 & $171-173$ & $69.39(69.48)$ & $4.28(4.26)$ & $15.56(15.58)$ & 450.5 \\
\hline 2 & $11 \mathrm{~b}$ & 72.3 & $152-154$ & $73.49(73.46)$ & $4.63(4.67)$ & $12.90(12.98)$ & 540.6 \\
\hline 3 & 11c & 65.2 & $120-122$ & $65.87(65.95)$ & $3.95(4.04)$ & $26.68(26.62)$ & 474.5 \\
\hline 4 & 11d & 42.3 & $154-156$ & $70.25(70.32)$ & $4.53(4.47)$ & $22.31(22.37)$ & 564.6 \\
\hline 5 & 13a & 53.6 & $119-122$ & $67.12(67.08)$ & $4.10(4.11)$ & $14.98(15.04)$ & 466.5 \\
\hline 6 & $13 \mathbf{b}$ & 81.2 & $95-97$ & $71.32(71.33)$ & $4.61(4.53)$ & $12.56(12.60)$ & 556.6 \\
\hline 7 & $13 \mathrm{c}$ & 50.2 & 101(dec.) & $63.86(63.79)$ & $4.02(3.91)$ & $25.59(25.75)$ & 490.5 \\
\hline 8 & 13d & 63.7 & $182-184$ & $68.41(68.37)$ & $4.39(4.35)$ & $21.73(21.75)$ & 580.6 \\
\hline
\end{tabular}

*Percentage yield, are on the basis of the final product

molecular weight. Table 1 contains the data of elemental analysis, $m / z$ values, melting point and percentage yields of the synthesized compounds.

\subsection{Antimicrobial activity}

Antibacterial activity carried out by well diffusion method using nutrient agar medium, DMSO as control and chloramphenicol is used as a standard bactericide. Antifungal activity was carried out by well diffusion method using potato dextrose agar (PDA) medium, DMSO as control and fluconazole is used as a standard fungicide. ${ }^{17-19}$ Biological properties of the synthesized compounds are screened for bacterial and fungal strains (tables 2 and 3). Most of the synthesized compounds showed inhibition property against the strains used. Among the test samples, 11b and 13a showed more activity when compared to the standards used. After comparing the zone of inhibition, the selected compounds were checked for their MIC (minimum inhibition concentration) values. The MIC values of less than $30 \mu \mathrm{g} / \mathrm{mL}$ are shown in table 3 . It is observed that, most of the samples showed promising activity. The compounds 11d and 13d with two traizole rings have been considered as good inhibitors.

\subsection{Antioxidant activity}

Antioxidant activity of the synthesized derivatives was evaluated using the DPPH free radical scavenging assay by standard methods. ${ }^{20,21}$ Data given in table 4 represents the DPPH free radical scavenging activity of the prepared compounds 11a-d and 13a-d. All the compounds showed scavenging activity of more than $50 \%$. Thus, the compounds are good antioxidant agents, which are capable of reacting with a free radical.

Table 2. Antimicrobial activity - zone of inhibition.

\begin{tabular}{|c|c|c|c|c|c|c|c|c|}
\hline \multirow{3}{*}{$\begin{array}{l}\text { Sl. } \\
\text { No }\end{array}$} & \multirow[b]{3}{*}{ Comp. } & \multicolumn{7}{|c|}{ Zone of inhibition (mm) } \\
\hline & & \multicolumn{4}{|c|}{ Antibacterial } & \multicolumn{3}{|c|}{ Antifungal } \\
\hline & & S. aureus & B. subtilis & S. typhi & E. coli & S. coccus & C. albicans & A. niger \\
\hline 1 & $11 a$ & 2 & 6 & 9 & 5 & 7 & 7 & 11 \\
\hline 2 & $11 b$ & 8 & 7 & 6 & 12 & 11 & 8 & 10 \\
\hline 3 & 11c & 5 & 6 & 6 & 7 & 5 & 7 & 6 \\
\hline 4 & 11d & 5 & 9 & 6 & 11 & 10 & 9 & 9 \\
\hline 5 & 13a & 9 & 10 & 7 & 6 & 11 & 10 & 11 \\
\hline 6 & 13b & 6 & 8 & 9 & 5 & 7 & 5 & 7 \\
\hline 7 & 13c & - & 2 & 8 & 4 & 6 & 7 & 6 \\
\hline 8 & $13 d$ & - & 3 & 9 & 11 & 12 & 6 & 5 \\
\hline 9 & Std1.* & 08 & 07 & 10 & 10 & 09 & - & - \\
\hline 10 & Std2.\# & - & - & - & - & - & 08 & 09 \\
\hline 11 & DMSO & 0 & 0 & 0 & 0 & 0 & 0 & 0 \\
\hline
\end{tabular}

*Chloramphenicol, ${ }^{*}$ Fluconazole 
Table 3. Antimicrobial activity - minimum inhibition concentration.

\begin{tabular}{|c|c|c|c|c|c|c|c|c|}
\hline \multirow{3}{*}{$\begin{array}{l}\text { Sl. } \\
\text { No }\end{array}$} & \multirow[b]{3}{*}{ Comp. } & \multicolumn{7}{|c|}{ MIC of the compounds $(\mu \mathrm{g} / \mathrm{mL})$} \\
\hline & & \multicolumn{4}{|c|}{ Antibacterial } & \multicolumn{3}{|c|}{ Antifungal } \\
\hline & & S. aureus & B. subtilis & S. typhi & E. coli & S. coccus & C. albicans & A. niger \\
\hline 1 & $11 a$ & - & 21 & 30 & 30 & 27 & 22 & 12 \\
\hline 2 & $11 b$ & 20 & 17 & - & 09 & 17 & 21 & 14 \\
\hline 3 & 11d & - & 12 & - & 14 & 19 & 13 & 19 \\
\hline 4 & 13a & 15 & 10 & - & 25 & 15 & 17 & 16 \\
\hline 5 & $13 b$ & - & 13 & - & - & 29 & 21 & 25 \\
\hline 6 & 13d & - & 25 & 29 & 12 & 14 & 30 & 27 \\
\hline
\end{tabular}

Table 4. Antioxidant activity by DPPH radical scavenging method.

\begin{tabular}{lcccccc}
\hline \multirow{2}{*}{$\begin{array}{l}\text { S1. } \\
\text { No. }\end{array}$} & Compounds & \multicolumn{5}{c}{$\%$ scavenging activity at different concentrations $(\mu \mathrm{g} / \mathrm{mL})$} \\
\cline { 3 - 7 } & 25 & 50 & 100 & 250 & 500 \\
\hline 1 & 11a & 12.25 & 24.25 & 56.87 & 71.83 & 81.76 \\
2 & $\mathbf{1 1 b}$ & 07.81 & 18.62 & 30.54 & 41.53 & 65.23 \\
3 & $\mathbf{1 1 c}$ & 10.52 & 21.85 & 54.23 & 61.28 & 78.75 \\
4 & $\mathbf{1 1 d}$ & 39.63 & 53.35 & 80.48 & 91.56 & 97.51 \\
5 & $\mathbf{1 3 a}$ & 12.86 & 21.56 & 32.79 & 42.13 & 56.52 \\
6 & $\mathbf{1 3 b}$ & 10.23 & 22.83 & 33.56 & 51.23 & 62.81 \\
7 & 13c & 06.32 & 12.52 & 21.83 & 34.54 & 49.42 \\
8 & 13d & 25.15 & 40.32 & 60.58 & 93.64 & 98.25 \\
9 & BHT* $^{*}$ & 12.35 & 25.72 & 58.51 & 86.25 & 94.32 \\
\hline
\end{tabular}

*Butylated hydroxytoluene

Among them, 11d and 13d were more active when compared to the standard BHT. The graphical representation of antioxidant activity is given in figure 1.

\subsection{Anthelmintic activity}

Results of anthelmintic activity of synthesized compounds are given in table 5. Graphical representation of anthelmintic activity is given as supplementary mate- rial (figure 2). It is clear that all the newly synthesized compounds exhibit more activity than the standard, against the earthworms used. Concentration of test samples and the standard used was $10 \mathrm{mg} / \mathrm{mL}$ in DMF. The impact of most of the compounds was more than that of standard. Activity may occur due to the presence of more potential quinoline, triazole and tetrazole rings in the compounds. Procedure for anthelmintic activity is supplied as Supplementary information.

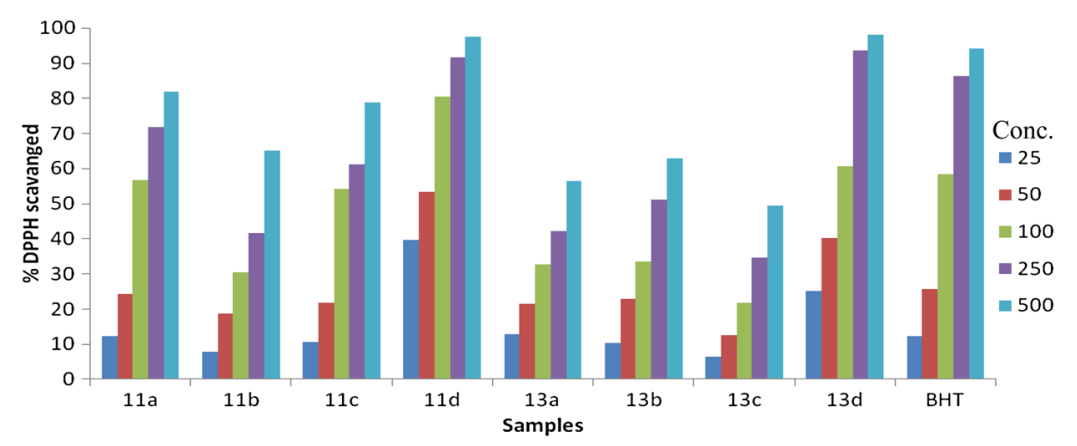

Figure 1. DPPH free radical scavenging activity. 
Table 5. Anthelmintic activity.

\begin{tabular}{lcccc}
\hline & & \multicolumn{3}{c}{ Time (min) } \\
\cline { 3 - 5 } & Compounds & Pin pinch & Paralysis & Death \\
\hline 1 & $\mathbf{1 1 a}$ & 12.07 & 15.00 & 28.50 \\
2 & $\mathbf{1 1 b}$ & 24.00 & 28.45 & 42.00 \\
3 & $\mathbf{1 1 c}$ & 13.45 & 21.00 & 28.00 \\
4 & $\mathbf{1 1 d}$ & 17.34 & 25.49 & 29.50 \\
5 & $\mathbf{1 3 a}$ & 21.50 & 27.00 & 36.00 \\
6 & $\mathbf{1 3 b}$ & 12.34 & 22.00 & 40.50 \\
7 & $\mathbf{1 3 c}$ & 14.00 & 22.54 & 25.00 \\
8 & 13d & 11.50 & 16.00 & 24.00 \\
9 & Albendazole & 18 & 25.00 & 28.20 \\
& (standard) & & & \\
10 & DMF & 18.39 & 32.47 & 46.08 \\
\hline
\end{tabular}

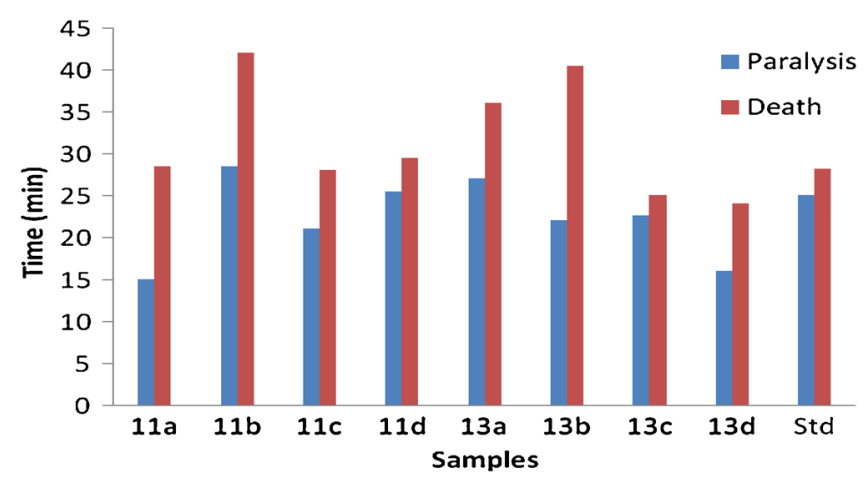

Figure 2. Anthelmintic activity.

Table 6. Docking scores.

\begin{tabular}{lcc}
\hline Sl. No. & Compounds & $\begin{array}{c}\text { Docking Score } \\
E_{\text {total }}\left(\mathrm{kJ} \mathrm{mol}^{-1}\right)\end{array}$ \\
\hline 1 & $\mathbf{1 1 a}$ & -241.95 \\
2 & $\mathbf{1 1 c}$ & -251.30 \\
3 & $\mathbf{1 3 c}$ & -286.69 \\
4 & $\mathbf{1 3 d}$ & -289.96 \\
5 & Albenzazole & -199.31 \\
\hline
\end{tabular}

\subsection{Docking studies}

In correlation to in vitro anthelmintic activity, it is thought worthwhile to carry out in silico studies to support the in vitro activity. Automated docking was used to assess the orientation of inhibitors bound in the active pockets of $\beta$-tubulin(PDB ID: 1OJ0). Molecular docking of selected ligands molecules with $\beta$ tubulin revealed that all the compounds have exhibited better docking score when compared to the standard albendazole. Procedure for docking is supplied as Supplementary information.

Among the newly synthesized molecules 11a, 11c, 13c and 13d have showed a good in vitro activity and docking score with $\beta$-tubulin protein. The compounds 11a, 11c, 13c and 13d have showed maximum binding affinity with the $-241.95,-251.30,-286.69$ and $-289.96 \mathrm{~kJ} \mathrm{~mol}^{-1}$, respectively. These docking scores are considered as good inhibitor of $\beta$-tubulin when compared to the standard drug albenzazole which is $-199.31 \mathrm{~kJ} \mathrm{~mol}^{-1}$, the values obtained in docking studies are tabulated in table 6.

Results showed that the synthesized compounds have less energy compared to the standard drugs, which suggest that synthesized compounds have excellent affinity towards the target protein.

\section{Conclusion}

The new compounds 11a-d and 13a-d were prepared by simple transformation and coupling reactions. The obtained products were characterized by elemental analysis, IR, NMR and mass spectral data. The synthesized compounds were screened for antimicrobial activity at the MIC level and in vitro antioxidant activity as well as anthelmintic activity. The compounds 11d and 13d showed more activity, which can be attributed to the triazole and tetrazole rings. All the compounds are potent towards the activities carried out. Docking study of the synthesized compounds was done with $\beta$-tubulin protein. All the compounds showed good docking scores.

\section{Supplementary information}

The supplementary information can be seen at www.ias. ac.in/chemsci.

\section{Acknowledgements}

Authors are thankful to the Department of Industrial Chemistry, Kuvempu University, Shimoga, Management and staff of Alkem Laboratories Ltd., R\&D center, Bangalore, Karnataka, India, Sri. Venkateshwara 
Industries and Mandli Industrial Estate, Shimoga for providing necessary facilities.

\section{References}

1. Levy S and Azoulay S 1994 J. Cardiovas. Electrophysiol. 5635

2. Wenckebach K F 1923 J. Am. Med. Assoc. 81472

3. (a) Bilker O, Lindo V, Panico M, Etiene A E, Paxton T, Dell A, Rogers M, Sinden R E and Morris H R 1998 Nature 392 289; (b) Roma G, Braccio M D, Grossi G, Mattioli F and Ghia H 2000 Eur. J. Med. Chem. 35 1021; (c) Chen Y L, Fang K C, Sheu J Y, Hsu S L and Tzeng C C 2000 J. Med. Chem. 44 2374; (d) Winstanley P A 2000 Parasitol. Today 16146

4. (a) Fang K C, Chen Y L, Sheu J Y, Wang T C and Tzeng C C $2000 \mathrm{~J}$. Med. Chem. 43 3809; (b) Chevalier J, Atifi S, Eyraud A, Mahamoud A, Barbe J and Pages J M 2001 J. Med. Chem. 44 4023; (c) Phan L T, Jian T, Chen Z, Qiu Y L, Wang Z, Beach T, Polemeropoulos A and Or Y S 2004 J. Med. Chem. 47 2965; (d) Benkovic S J, Baker S J, Alley M R K, Woo Y H, Zhang Y K, Akama T, Mao W, Baboval J, Rajagopalan P T R, Wall M, Kahng L S, Tavassoli A and Shapiro L 2005 J. Med. Chem. $\mathbf{4 8} 7468$

5. (a) Majerz-Maniecka K, Oleksyn B, Musiol R, Podeszwa B and Polanski J In Abstracts of Papers, Joint Meeting on Medicinal Chemistry, Vienna, Austria 2005, Sci. Pharm. 73 194; (b) Vargas L Y, Castelli M V, Kouznetsov V V, Urbina J M, Lopez S N, Sortino M, Enriz R D, Ribas J C and Zacchino S 2003 Bioorg. Med. Chem. 11 1531; (c) Singh M, Singh M P and Ablordeppey S Y 1996 Drug Dev. Ind. Pharm. 22 377

6. (a) Dassonneville L, Lansiaux A, Wattelet A, Wattez N, Mahieu C, Van Miert S, Pieters L and Bailly C 2000 Eur. J. Pharmacol. 409 9; (b) Dassonneville L, Bonjean K, De Pauw-Gillet, Colson M C, Houssier $\mathrm{P}$, Quetin-Leclercq $\mathrm{C}$, Angenot $\mathrm{J}$ and Ablordeppey L S Y 2002 Bioorg. Med. Chem. 10 1337; (c) Bailly C 1999 Biochemistry 38 7719; (d) Bailly C, Laine W, Baldeyrou B, De Pauw-Gillet M -C, Colson P, Houssier
C, Cimanga K, Miert S V, Vlietinck A J and Pieters L 2000 AntiCancer Drug Des. 15191

7. (a) Jones G 1996 Comprehensive heterocyclic chemistry II (eds) A R Katritzky, C W Rees and E F Scriven (Pergamon: Oxford) 5, 167; (b) Holla B S, Mahalinga M, Karthikeyan M S, Akberalib P M and Shettyc N S 2006 Bioorg. Med. Chem. 142040

8. (a) Smirnov R F, Tikhomirov B I, Marinchenko G V and Yakubchik A I 1973 Polym. Sci. U.S.S.R. 15 832; (b) Całus S, Gondek E, Danel A, Jarosz B, Pokładko M and Kityk A V 2007 Mater. Lett. 613292

9. Caeiro G, Lopes J M, Magnoux P, Ayrault P and Ribeiro F R 2007 J. Catal. 249234

10. Carini D J, Duncia J V, Aldrich $\mathrm{P}$ E, Chiu A T, Johnson A L, Pierce M E, Price W A, Santella J B, Wells G J, Wexler R R, Wong P C, Yoo S E and Timmermans PBWM 1991 J. Med. Chem. 342525

11. Kohler B, Langer M and Mosandl T 1998 Ger. Pat. Appl. DE19632643C1

12. Amatore C, Jutand A and Negri S 1990 J. Organomet. Chem. 390389

13. Sharp M J and Snieckus V 1985 Tetrahedron Lett. 26 5997

14. Copar A, Antoncic L and Antoncic M T 2006 Int. Pat. Appl. WO 2006/103068A1

15. Shashikumar N D, Krishnamurthy G, SundaraRajRao K, Shridhara K, BhojyaNaik H S and Nagarajan K 2010 Org. Process Res. Dev. 14918

16. Sharath N, BhojyaNaik H S, VinayKumar B and JoyHoskeri 2011 Brit. J. Pharma. Res. 146

17. (a) Bhimagouda S P, Krishnamurthy G, Bhojyanaik H S, Prashant R L and Manjunath G 2010 Eur. J. Med. Chem. 45 3329; (b) Shashikumar N D 2013 J. Chem. Article ID 240381, 20131

18. Roger J S, Asitha A, Scot C, John L, Mohammed A, Kashem H K, Josephine K, Jennifer A, Kowalski S S, Pullen T, Roma J P, Roth C R, Sarko N S, Wilsyn M P, Winters J P and Wolak C L 2007 Bioorg. Med. Chem. Lett. 173660

19. Ozden O G, Taner E, Hakan G and Sulhiye Y 2007 Bioorg. Med. Chem. Lett. 172233

20. Rohini D S, Alexandar M J N and Chandrasekar 2011 RJPBCS 2194

21. Gbolade A A and Adeyemi A A 2008 Fitoterapia 79223 